\title{
Eksistensi wisata tani betet dalam kegiatan ekonomi masyarakat lokal di Kabupaten Nganjuk (Studi kasus wisata tani di Desa Betet Kecamatan Ngronggot)
}

\author{
Vionita Agustyaningtias, Hari Wahyono* \\ Universitas Negeri Malang, Jl. Semarang No. 5 Malang, Jawa Timur, Indonesia \\ *Penulis korespondensi, Surel: hari.wahyono.fe@um.ac.id
}

Paper received: 25-8-2021; revised: 8-9-2021; accepted: 15-9-2021

\begin{abstract}
Kabupaten Nganjuk adalah salah satu daerah yang dinilai sangat potensial dalam mengembangkan industri pariwisatanya, terutama di bidang wisata alam. Dengan wilayah yang terletak di dataran rendah dan pegunungan. Dalam hal ini pemerintah memberikan penyuluhan tentang perwujudan desa wisata sebagai upaya peningkatan pendapatan desa, sehingga mampu memotivasi masyarakat setempat untuk mendirikan desa berbasis wisata. Di Desa Betet Kecamatan Ngronggot ini juga memiliki potensi alam mengenai wisata desa yaitu Wisata Tani Betet. Dimana wisata tani ini terletak di dekat persawahan warga setempat dengan memanfaatkan lahan tanam tebu dan air sungai mengalir.
\end{abstract}

Keywords: wisata tani; kegiatan ekonomi masyarakat lokal; peran wisata tani dalam peningkatan perekonomian.

\begin{abstract}
Abstrak
Nganjuk Regency is one of the areas that is considered very potential in developing its tourism industry, especially in the field of natural tourism. With areas located in the lowlands and mountains. In this case the Government provides counseling on the realization of tourism villages as an effort to increase village income, so as to motivated local communities to establish tourism based villages. In Betet Village, Ngronggot District, it also has natural potential regarding village tourism, namely Betet Farmers Tourism. Where this farming tourism is located near the rice fields of local residents by utilizing sugar cane planting land and flowing river water.
\end{abstract}

Kata kunci: farm tourism; economic activities of local communities; the role of farming tourism in increasing the economy.

\section{Pendahuluan}

Paradigma pembangunan pariwisata mampu dijadikan penghapusan kemiskinan (Proverty Alleviation), karena dapat memberikan kesempatan bagi seluruh rakyat untuk berusaha dan bekerja, kunjungan wisatawan dapat memberikan manfaat bagi peningkatan kesejahteraan masyarakat. Pariwisata mampu berperan dalam penghapusan kemiskinan dengan mengandalkan potensi alam dan budaya bagi kepentingan pariwisata. Selain itu peningkatan ekonomi dan industri lokal dapat dikembangkan dengan penggunaan bahan dan produk lokal dalam proses pelayanan di pariwisata tersebut (Hadiwijoyo.S.R, 2012:50:51).

Kabupaten Nganjuk adalah salah satu daerah yang dinilai sangat potensial dalam mengembangkan industri pariwisatanya, terutama di bidang wisata alam. Kabupaten Nganjuk memiliki kondisi dan struktur tanah yang cukup produktif untuk berbagai tanaman, baik tanaman pangan maupun tanaman perkebunan. Dalam hal ini pemerintah memberikan penyuluhan tentang perwujudan desa wisata sebagai upaya peningkatan pendapatan desa, sehingga mampu memotivasi masyarakat setempat untuk mendirikan desa berbasis wisata. 
Wilayah desa wisata di Kabupaten Nganjuk berada pada daerah yang asri dengan udara yang sejuk, tentunya oleh ketersediaan fasilitas dan aksesibilitas, dua diantaranya adalah Desa Wisata Petung Ulung dan Desa Wisata Kweden.

Menanggapi hal tersebut di daerah lain juga tidak kalah dengan desa yang mampu memiliki potensi mengenai wisata desa, salah satunya di Wisata Tani Betet dimana letaknya di Dusun Betet Desa Betet Kecamatan Ngronggot Kabupaten Nganjuk. Wisata tani ini berbeda dengan wisata desa yang lainnya karena wisata tani betet masih dalam jangkauan yang belum luas namun menjadi salah satu wisata yang ada di Desa Betet Kecamatan Ngronggot dan murni dikelola oleh swadaya masyarakat sekitar.

Desa wisata menurut Muljadi (2009:27) yaitu, desa wisata merupakan daerah wisata yang melibatkan anggota masyarakat desa dengan segala perangkat yang dimilikinya. Desa wisata tidak hanya berpengaruh pada ekonominya, tetapi juga sekaligus dapat melestarikan lingkungan alam dan sosial budaya masyarakat terutama berkaitan dengan nilai-nilai kebersamaan, kekeluargaan, kegotongroyongan dan lain-lain. Sebelum adanya Wisata Tani Betet ini, kondisi sosial ekonomi masyarakat Desa Betet Kecamatan Ngronggot juga masih kurang atau belum cukup baik. Masyarakat sekitar hanya mengandalkan pekerjaan yang datangnya tidak setiap hari, namun ada juga beberapa masyarakat yang mengandalkan pendapatan dari hasil panen yang mereka tanam di lahan yang mereka miliki. Hal itupun juga tidak semua masyarakat memiliki lahan yang luas dari hasil yang mereka tanami. Ada juga yang hanya menjadi buruh petani dan memiliki usaha pembuatan uleg-uleg atau bisa disebut dengan gerabah. Selain itu, para pemuda daerah sekitar sebelumnya juga tidak memiliki pekerjaan yang tetap, ada yang bekerja di luar kota dan bahkan juga ada yang menganggur. Namun dengan adanya perkembangan desa yang dilakukan oleh kelompok wisata desa dan pemerintah desa mampu menciptakan suatu desa tersebut dapat dijadikan sebagai wisata desa agar mampu mewujudkan dampak positif bagi masyarakat Desa Betet itu sendiri terutama dengan adanya wisata tani ini mampu meningkatkan penghasilan masyarakat sekitar.

Awal mula dari wisata tani betet ini hanya memanfaatkan sungai apur yang dekat dengan persawahan warga, yang mana sungai tersebut awalnya kotor dan tidak berfungsi bagi masyarakat sekitar. Atas dukungan kegiatan pertanian dari pemerintah desa, maka sungai apur tersebut diolah agar bisa memberikan manfaat untuk para petani yang memiliki sawah di dekat sungai apur tersebut. Pada saat itulah kelompok sadar wisata (pokdarwis) Desa Betet memiliki ide untuk memanfaatkan sungai apur tersebut dan lahan yang ada dengan mengajak masyarakat sekitar untuk melakukan kerja bakti atau gotong royong membersihkan lahan sekitar sungai apur agar dapat ditanami tanaman bunga di sekeliling sungai apur agar dapat mempercantik daerah sungai apur. Selain itu masyarakat juga melakukan kerja bakti atau gotong royong untuk membuat tempat-tempat yang bisa dimanfaatkan anak-anak milenial saat ini agar bisa menikmati daerah sungai yang ada dengan mengabadikan moment atau kegiatan yang berlangsung ketika berkunjung di sebuah wisata dengan menikmati spot-spot foto yang sudah disediakan. Dari situlah wisata tersebut bisa dikenal masyarakat sekitar dan masyarakat umum luar daerah juga, karena dari satu pengunjung yang sudah menikmati wahana wisata tani tentunya akan mempengaruhi pengunjung yang lainnya. Dengan begitu peningkatan pemanfaatan lahan yang dilakukan pemerintah desa dan pengelola desa wisata agar dapat membuat nuansa baru atau desain baru yang mana hal tersebut mampu menambah pengunjung yang datang dan sekaligus mampu meningkatkan pendapatan dari wisata tani. 
Untuk meningkatan penghasilan masyarakat Desa Betet Kecamatan Ngronggot, pemerintah desa dan pengelola wisata bisa melakukan pengembangan dalam hal pengelolaan lahan wisata tani tersebut agar mampu mewujudkan suatu kegiatan ekonomi yang bisa dilakukan oleh masyarakat sekitar. Hal tersebut bisa dilakukan dengan menambah wahana yang ada di wisata tani betet ataupun menciptakan inovasi yang baru agar wisata tani tersebut mampu dikenal dan dikunjungi masyarakat lokal maupun masyarakat luar daerah. Dengan adanya inovasi baru yang diciptakan, maka dapat menarik pengunjung agar memiliki keinginan untuk mengunjungi wisata tani betet tersebut. Dengan banyaknya pengunjung yang datang tentu juga akan menambah penghasilan bagi masyarakat daerah setempat yang melakukan kegiatan ekonomi di wisata tani betet ini. Selain itu, wisata tani betet ini dapat bersaing dalam lingkup wisata daerah maupun tingkat yang lebih tinggi. Dengan bertambahnya pengunjung setiap harinya di wisata tani betet maka secara otomatis pendapatan dari wisata tani juga meningkat dan masyarakat yang terlibat seperti para pedagang-pedagang, parkir atau pengelolaan wahana perahu dan sepeda air juga mampu meningkatkan penghasilan di setiap harinya. Dengan begitu masyarakat lokal Desa Betet akan merasakan peningkatan perekonomian dan mampu memenuhi kebutuhan hidupnya seharihari dari penghasilan yang dilakukan di wisata tani ini.

\section{Metode}

Penelitian ini dilakukan untuk mengetahui eksistensi wisata tani dalam kegiatan ekonomi masyarakat lokal di Desa Betet dengan menggunakan pendekatan induktif. Peneliti memilih metode kualitatif dengan pertimbangan bahwa masalah dalam penelitian ini membutuhkan informasi yang mendalam untuk memudahkan mengungkapkan fakta-fakta yang terjadi di lapangan. Dalam hal ini, peneliti menggunakan teknik wawancara untuk menggali informasi secara mendalam. Selain itu, peneliti juga mengamati secara langsung bagaimana kondisi kegiatan ekonomi yang terjadi di wisata tani. Dalam penelitian ini, diharapkan peneliti dan informan memiliki keterikatan emosional sehingga dapat menghasilkan data yang akurat. Jenis penelitian yang digunakan dalam penelitian ini adalah kualitatif deskriptif.

Dalam penelitian ini data yang digunakan adalah data primer dan data sekunder. Data primer didapat langsung dari informan melalui wawancara dan observasi. Pemilihan subjek penelitian menggunakan purposive sampling, yaitu peneliti sudah mengetahui siapa yang akan dijadikan informan berdasarkan kriteria yang dipilih. Dalam penelitian ini sumber data primer adalah Pemerintah Desa Betet (Kamituwo), Pengelola wisata tani betet, Staf Dinas Pariwisata dan pelaku ekonomi di wisata tani betet. Sedangkan pada data sekunder didapatkan melalui pengelola wisata tani mengenai profil wisata serta studi pustaka dan internet.

\section{Hasil dan Pembahasan}

\subsection{Hasil}

Dalam penelitian yang sudah dilaksanakan, peneliti menemukan temuan penelitian yang telah dijabarkan sebagai mana yang sudah didapatkan dalam penelitian tersebut antara lain yaitu:

Asal mula dari adanya wisata tani ini disebabkan karena suatu permasalahan mengenai sungai apur yang dirasa sangat kumuh dan tidak memiliki manfaat apapun bagi kegiatan pertanian masyarakat sekitar. 
Pada akhirnya pemerintah desa memberikan dukungan pada kegiatan pertanian di Desa Betet untuk diadakan normalisasi sungai apur dengan perjanjian yang sudah diajukan dengan PG MRICAN.

Pada tahun 2016 Dinas Perikanan ikut serta dalam peresmian normalisasi sungai apur dengan memberikan bibit ikan bersisik 10.000 ekor guna untuk mengembalikan keanekaragaman hayati serta agar kesimbangan ekosistem sungai dapat terjaga dengan baik.

Pada tahun 2017 kelompok sadar wisata (pokdarwis) Desa Betet diberikan modal awal sejumlah Rp 10.000.000 guna untuk mendirikan wisata tani dimana yang awalnya digunakan untuk pembangunan sarana dan prasarana di wisata tani betet.

Tepat pada tanggal 20 Januari 2019 awal dari beroperasinya wisata tani serta pemanfaatan wahana perahu dan sepeda air dari dana sisa bumdes dan iuran pengelola wisata tani.

Wisata tani betet ini secara murni dikelola masyarakat sekitar atau pengelola wisata karena wisata tani murni dari swadaya masyarakat.

Dengan adanya wisata tani di Desa Betet ini mampu menimbulkan kegiatan ekonomi bagi masyarakat lokal daerah wisata tani.

Selain itu masyarakat yang terlibat di wisata tani tentunya juga dapat meningkatkan pendapatan yang dihasilkan dan mampu mencukupi kebutuhan hidup.

Adapun kegiatan ekonomi yang dilakukan masyarakat sekitar meliputi Berdagang, parkir, pemanfaatan wahana perahu dan sepeda air serta wahana permainan anak-anak.

Peran wisata tani sangat penting dalam peningkatan perekonomian masyarakat lokal Desa Betet.

\subsection{PEMBAHASAN}

Pada bab ini akan membahas tentang hasil temuan penelitian yang akan ditinjau dari segi teoritis dan pendapat dari peneliti.

\subsubsection{Asal mula adanya wisata tani di Desa Betet Kecamatan Ngronggot Kabupaten Nganjuk}

Pariwisata yang tersebar di Indonesia mempunyai ciri khas pada setiap daerahnya. Dalam hal ini, dapat mendorong pemerintah pusat maupun daerah untuk melakukan pengelolaan dan pemanfaatan yang berdampak bagi pembangunan daerah tersebut. Munculnya tempat-tempat wisata tersebut dapat meningkatkan pendapatan daerah dan mampu meningkatkan potensi yang dimiliki daerah seperti halnya dengan peningkatan kualitas sumber daya manusia (Rahmatin, 2016). Salah satu potensi yang terus berkembang saat ini adalah desa wisata. Desa wisata merupakan sebagian atau keseluruhan wilayah desa yang memiliki potensi, produk dan aktivitas wisata yang dapat dimanfaatkan untuk pengembangan pariwisata dan dikelola oleh kelompok masyarakat di desa (Ida Bagus Suryawan, 2015:9) 
Berdasarkan dari hasil penelitian dapat diketahui bahwa wisata tani di Desa Betet Kecamatan Ngronggot ini merupakan wisata yang baru dikembangkan beberapa tahun terakhir ini oleh masyarakat setempat dengan dukungan-dukungan dari berbagai banyak pihak. Awal dari adanya wisata tani ini disebabkan oleh permasalahan sungai apur yang berdekatan dengan persawahan warga yang mana sungai apur tersebut membuat warga resah akan akibat air yang menggenangi sawah ketika musim hujan tiba. Namun pada saat itu pemerintah desa mengetahui keresahan yang dirasakan warga mengenai sungai apur tersebut. Sehubungan dengan hal tersebut, kegiatan pertanian di Desa Betet mendapat dukungan dari pemerintah desa, salah satu dukungan terhadap pertanian adalah dengan adanya normalisasi sungai apur.

Dengan terealisasinya normalisasi sungai apur di Desa Betet ini dan sungai apur yang awalnya keruh serta tidak memiliki manfaat apapun. Dengan terealisasinya hal tersebut sungai apur ini mampu memperindah daerah sekitar serta memberikan dampak yang positif bagi petani dan masyarakat sekitar. Dengan begitu ada sebuah ide dari kelompok sadar wisata (pokdarwis) Desa Betet ini untuk membuat desa tersebut menjadi sebuah wisata dengan memanfaatkan sungai apur yang ada. Oleh karena itu, dengan adanya sungai apur yang tempatnya berdekatan dengan persawahan warga, kelompok sadar wisata memiliki ide untuk memberikan nama dengan julukan "WISATA TANI BETET", maksud dari nama tersebut yaitu mengangkat sebuah wisata dengan membawa hasil tanam tani yang dilakukan masyarakat di Desa Betet. Karena Desa Betet itu sebagian penduduk bermata pencaharian sebagai petani serta awal mula dari ide normalisasi sungai apur bertujuan untuk kegiatan pertanian, oleh karena itu kelompok sadar wisata (pokdarwis) mengangkat dengan julukan tersebut. Dengan adanya wisata tani di Desa Betet Kecamatan Ngronggot ini tentunya mampu untuk dijadikan daya tarik wisata dimana di Desa Betet ini memiliki sumber alam yang berpotensi dan mampu dijadikan daya Tarik bagi pengunjung. Hal ini selaras dengan (Suryadana \& Oktavia, 2015) bahwa daya tarik wisata merupakan salah satu unsur yang menentukan suatu daerah tersebut menjadi destinasi. Daya tarik tersebut berasal dari unsur-unsur geografi suatu daerah yang muncul secara alami.

\subsubsection{Upaya Dinas Pariwisata untuk mempertahankan eksistensi wisata tani di Desa Betet Kecamatan Ngronggot Kabupaten Nganjuk}

Berdasarkan hasil penelitian, perkembangan wisata desa yang ada di Kabupaten Nganjuk sudah berjalan dengan baik. Tentunya pada saat ini di masing-masing desa rata-rata sudah mampu mendirikan wisata desa yang mana wisata tersebut masih dalam lingkup yang kecil dan dikelola masyarakat sekitar. Dalam hal ini, tentunya untuk mengembangkan suatu wisata yang ada di desa juga diperlukan suatu upaya atau langkah-langkah yang mampu memiliki tujuan untuk tetap menjaga dan mempertahankan wisata desa tersebut agar mampu bersaing dengan wisata-wisata yang lain.

Untuk mempertahankan wisata tani di Desa Betet ini murni dilakukan dari pengelola wisata tani atau masyarakat setempat, dimana pada saat ada himbauan untuk menutup sementara objek wisata pada saat pandemi Covid-19 saat ini juga ada suatu kegiatan yang tetap dilakukan oleh pengelola wisata tani seperti halnya kegiatan pengecekan atau perbaikan perahu, perbaikan jalan keluar untuk pengunjung dan pengendara kereta kelinci. Dengan adanya kegiatan yang tetap dilakukan oleh pengelola wisata tani tentu juga suatu upaya agar wisata tani betet itu mampu bertahan dan dikelola dengan baik. Upaya yang dilakukan 
pengelola wisata tani betet agar mampu mempertahankan wisata tani betet ini dikembalikan lagi dengan sebelum adanya wisata tani atau awal perintisan wisata tani betet ini. Dimana yang awalnya perintisan masyarakat yang bergabung hanya memperoleh pendapatan yang kecil dan minim namun dengan semakin berkembangnya wisata tani ini merubah perolehan yang dihasilkan. Dengan adanya hal tersebut pengelola wisata melakukan upaya mempertahankan wisata tani ini agar masyarakat yang sudah terlibat mampu mencukupi kebutuhan hidup sehari-hari dan mampu meningkatkan perekonomian yang terjadi. Dengan semakin berkembangnya wisata tani betet ini tentu juga akan membawa dampak positif yang dirasakan masyarakat Desa Betet. Hal ini selaras dengan penelitian yang dilakukan oleh Hamid (2016) mengungkapkan bahwa sebelum adanya pengembangan pariwisata masyarakat sekitar banyak yang menganggur atau tidak memiliki pekerjaan namun dengan adanya pengembangan wisata tersebut banyak masyarakat yang mendapat peluang kerja seperti dengan juru parkir, menjual souvenir di sekitar objek wisata tersebut.

\subsubsection{Kegiatan ekonomi masyarakat lokal wisata tani di Desa Betet Kecamatan Ngronggot Kabupaten Nganjuk}

Menurut Imam Chourmain dan Prihatin, Kegiatan ekonomi merupakan upaya manusia untuk memenuhi kebutuhan dengan barang dan jasa yang mempunyai kegunaan alternatif. Kegiatan ekonomi juga penting karena kegiatan ini menunjukkan keharusan manusia untuk aktif dan bekerja agar dapat mencukupi kebutuhan hidup. Dengan adanya kegiatan ekonomi yang dilakukan masyarakat tentu juga akan memperoleh pendapatan yang dihasilkan dan mampu untuk mencukupi kebutuhan hidupnya. Sedangkan masyarakat lokal menurut Soekanto (2007:132) mengatakan bahwa masyarakat lokal merupakan masyarakat setempat, yaitu warga sebuah desa, kota, suku atau bangsa. Dalam pengelolaan objek wisata tentu juga melibatkan masyarakat sekitar objek wisata tersebut. Dalam hal ini dapat dikaitkan dengan adanya wisata tani di Desa Betet Kecamatan Ngronggot Kabupaten Nganjuk yang mampu menimbulkan kegiatan ekonomi yang dapat dilakukan masyarakat sekitar wisata tani. Kegiatan ekonomi yang dilakukan masyarakat Desa Betet tentunya berbeda-beda guna untuk mencukupi kebutuhan hidup sehari-hari. Sama halnya ketika masyarakat bekerja sebagai pedagang tentu juga akan memperoleh pendapatan dari hasil berdagangnya, namun ketika ada masyarakat yang belum memiliki pekerjaan tentu juga tidak akan mendapatkan penghasilan. Dari sini dapat diketahui bahwa masyarakat Desa Betet ada yang memiliki pekerjaan namun dengan penghasilan yang cukup, ada juga yang memiliki pekerjaan dengan penghasilan yang rendah dan ada pula yang belum memiliki pekerjaan atau pengangguran. Dengan begitu tentunya tidak semua masyarakat memiliki pekerjaan yang sama agar dapat mencukupi kebutuhan hidup. Namun dengan adanya wisata tani di Desa Betet dapat memberikan kesempatan kerja bagi masyarakat sekitar. Hal ini selaras dengan pendapat dari (Pendit, 2006) mengungkapkan bahwa kesempatan kerja dalam pariwisata tersebut meliputi usaha akomodasi, restoran, pengrajin serta bidang kerja dan jasa yang lainnya. Selain itu, sebagai industri kepariwisataan dapat memberikan peluang kepada para petani untuk memasarkan produk yang dihasilkan.

Di Desa Betet Kecamatan Ngronggot ini mampu mewujudkan sebuah desa yang mewujudkan sebuah wisata yang ada di desa itu sendiri dan mampu dikelola sendiri oleh masyarakat sekitar. Dengan begitu dampak positif yang dirasakan masyarakat sekitar tentunya sangat didapatkan dengan adanya wisata tani tersebut. Tujuan dari wisata tani betet 
ini juga sebagai pemberdayaan masyarakat agar mampu merangkul masyarakat sekitar yang masih belum memiliki pekerjaan atau bahkan untuk meningkatkan penghasilan yang masih rendah serta dapat melestarikan keindahan alam sekitar. Dalam hal ini sesuai dengan pendapat dari (Arsyad: 2009) bahwa pembangunan ekonomi daerah merupakan suatu proses dimana pemerintah daerah dan masyarakat mampu mengelola sumberdaya-sumberdaya yang ada dan membentuk pola kemitraan antara pemerintah dan sektor swasta untuk menciptakan lapangan pekerjaan baru dan mampu merangsang kegiatan ekonomi.

Berdasarkan hasil penelitian, dengan adanya wisata tani betet ini masyarakat sekitar dapat bergabung dan melaksanakan kegiatan ekonomi seperti halnya berdagang, parkir, pemanfaatan wahana perahu dan sepeda air serta permainan anak-anak. Di dalam sebuah wisata tentunya juga melibatkan masyarakat sekitar untuk turut mendukung kegiatan yang dilakukan. Masyarakat sekitar yang terlibat dapat berjualan di lapak-lapak yang sudah tersedia dengan begitu juga mampu memberikan keuntungan bagi objek wisata agar pengunjung dapat menikmati kuliner yang ada di wisata tani betet serta mampu memberikan keuntungan untuk pedagang itu sendiri. Dengan kegiatan ekonomi yang dilakukan tentu juga meningkatkan pendapatan yang diperoleh, yang awalnya hanya memperoleh pendapatan kurang dari cukup namun dengan adanya wisata tani betet ini masyarakat mampu memperoleh pendapatan yang cukup untuk memenuhi kebutuhan hidup.

Dari kegiatan ekonomi masyarakat yang sudah dilakukan mulai dari masyarakat yang berdagang, parkir, pemanfaatan wahana perahu dan sepeda air serta permainan anak-anak tentunya dari masing-masing masyarakat yang terlibat tidak memperoleh pendapatan yang sama hanya saja mereka mampu mencukupi kebutuhan yang dijalani dengan adanya wisata tani betet ini. Pihak pengelola wisata tani juga memprioritaskan masyarakat sekitar untuk bergabung sebagai pelaku ekonomi di dalamnya karena dikembalikan dengan tujuan awal dari wisata tani betet ini untuk merangkul masyarakat sekitar yang belum memiliki pekerjaan serta mampu menambah pendapatan masyarakat sekitar yang masih rendah. Hal ini selaras dengan pendapat dari (Yoeti, 2008:20-21) dalam Rahmita Putri Febriana (2017) bahwa dengan adanya kegiatan pariwisata dapat menimbulkan dampak positif seperti halnya mampu meningkatkan penyerapan kesempatan kerja (employment) serta dapat meningkatkan pendapatan masyarakat sekitar.

\subsubsection{Peran Wisata Tani di Desa Betet Kecamatan Ngronggot Kabupaten Nganjuk dalam peningkatan perekonomian masyarakat lokal}

Di sebuah desa yang sudah memiliki potensi mengenai wisata yang dapat menjadi keunggulan di desa tersebut tentu sangat memiliki peran yang sangat penting. Sesuai dengan Peraturan Menteri Dalam Negeri Nomor 33 Tahun 2009 Tentang Pengembangan Ekowisata di Daerah yang diantaranya bertujuan untuk meningkatkan pendapatan masyarakat lokal. Berdasarkan hasil penelitian dapat diketahui bahwa dengan adanya wisata tani betet ini mampu memberikan dampak positif bagi masyarakat sekitar, salah satunya dalam peluang kerja. Objek wisata merupakan salah satu sarana yang tepat dalam meningkatkan kemajuan ekonomi masyarakat baik lokal maupun global. Adanya suatu wisata juga mempunyai manfaat seperti menjaga kelestarian alam dan mengembangkan budaya lokal untuk kemajuan ekonomi masyarakat (Anggraeni, 2013). Berdasarkan hasil penelitian ini dapat dikaitkan dengan adanya wisata tani di Desa Betet Kecamatan Ngronggot Kabupaten Nganjuk yang sudah mampu memberikan perkembangan di desa tersebut. Dengan adanya wisata tani ini juga 
mampu memberikan dampak positif yang dirasakan oleh masyarakat setempat dimana mampu merubah kegiatan ekonomi yang ada serta dapat meningkatkan perekonomian masyarakat sekitar. Hal ini sesuai dengan pendapat dari I. Pitana (2009), dimana pembangunan dan pengembangan pariwisata secara langsung akan memprovokasi dan melibatkan masyarakat secara langsung, sehingga membawa dampak terhadap masyarakat sekitar, baik dampak positif maupun negatif. Terwujudnya wisata tani ini juga mendapat respon yang positif dari masyarakat sekitar yang mana masyarakat tersebut turut mendukung pembangunan dan pengelolaan wisata tani betet ini. Masyarakat sebagai salah satu pemangku kepentingan kedudukan dan peran penting dalam mendukung keberhasilan pembangunan suatu wisata (Topowijoyo, 2018). Tanpa adanya dukungan dari masyarakat ataupun pemerintah desa tentunya wisata tani ini juga tidak akan berjalan dan berkembang. Dalam hal ini peran pemerintah juga dibutuhkan untuk mendidik, menghimbau dan mengelola wisata dalam kaitannya dengan kesejahteraan masyarakat sekitar (Oktini, 2004). Dengan banyaknya dukungan-dukungan yang didapatkan juga dapat memberikan arah yang baik untuk menuju wisata desa yang mampu bersaing dengan wisata yang lain.

\section{Simpulan}

Asal mula adanya wisata tani betet ini muncul karena adanya dukungan dari pemerintah desa yang mampu mendukung kegiatan pertanian di Desa Betet ini untuk melaksanakan normalisasi sungai apur. Dalam merealisasikan normalisasi sungai apur tersebut tentu adanya dukungan dari pihak lain seperti halnya dengan PG MRICAN yang mampu membantu merealisasikan sungai apur dengan suatu perjanjian yang dibuat dengan pemerintah desa. Dengan adanya normalisasi sungai apur tersebut masyarakat sekitar memiliki ide untuk mengembangkan desa dengan memanfaatkan sungai apr tersebut untuk dijadikan wisata tani di Desa Betet.

Dalam mempertahankan wisata tani betet ini tentunya terdapat upaya yang dilakukan. Dalam hal ini Dinas Pariwisata sebagai pendamping, mengawasi dan memberikan himbauan terkait informasi yang mampu memberikan kemajuan atau perbaikan untuk wisata tani betet. Dalam hal ini Dinas Pariwisata tidak ikut campur tangan secara penuh terkait pengelolaan yang dilakukan. Untuk mempertahankan wisata tani betet secara murni dilakukan oleh pengelola wisata terkait dengan kegiatan yang dilakukan seperti halnya dalam perbaikan sarana dan prasarana di wisata tani betet.

Dengan adanya wisata tani betet ini tentunya dapat menimbulkan kegiatan ekonomi yang baru untuk masyarakat setempat, dimana masyarakat dapat melakukan kegiatan ekonomi dengan berdagang, parkir, pemanfaatan wahana perahu dan sepeda air serta permainan anak-anak. Dengan adanya kegiatan ekonomi yang dilakukan juga akan memberikan dampak positif bagi masyarakat sekitar untuk memperoleh pendapatan yang mampu untuk mencukupi kebutuhan hidupnya. Dengan adanya wisata tani betet ini juga dapat merangkul masyarakat sekitar yang belum memiliki pekerjaan dan mampu meningkatkan pendapatan sehari-hari.

Peran wisata tani betet ini sangat penting untuk masyarakat sekitar Desa Betet, dimana dengan adanya wisata tani betet ini mampu mewujudkan Desa Betet untuk memiliki potensi yang dapat dikenal masyarakat luar. Selain itu juga mampu meningkatkan perekonomian masyarakat sekitar Desa Betet. 


\section{Daftar Rujukan}

Anggraeni, A. A. (2013). Analisis dampak ekonomi wisata bahari terhadap pendapatan masyarakat di Pulau Tidung. Reka Loka, 1(1), 220893.

BPS. (2020) Kecamatan Ngronggot Dalam Angka. tersedia di https://nganjukkab.bps.go.id/publication/2020/09/28/3ed49e45c15201982dea3fcf/kecamatanngronggot-dalam-angka-2020.html

Chourmain, Imam dan Prihatin. (1994). Pengantar Ilmu Ekonomi. Jakarta: Direktorat Jenderal Pendidikan Tinggi Departemen Pendidikan Dan Kebudayaan.

E.St Harahap, dkk. (2007). Kamus Besar Bahasa Indonesia. Bandung: Balai Pustaka.

Hadiwijoyo, Suryo Sakti. (2012). Perencanaan Pariwisata Perdesaan Berbasis Masyarakat (Sebuah Pendekatan Konsep ), Yogyakarta : Graha Ilmu

Hermawan, H. (2016). Dampak pengembangan Desa Wisata Nglanggeran terhadap ekonomi masyarakat lokal. Jurnal Pariwisata, 3(2), 105-117. https://doi.org/10.31219/osf.io/xhkwv

Pitana, I. (2009). Pengantar Ilmu Pariwisata. Yogyakarta: Andi.

Juniyesnani, A. B., Studi, P., Akuntansi, P., Keguruan, F., Ilmu, D. A. N., \& Surakarta, U. M. (2020). Pemberdayaan Masyarakat menuju Social Entrepreneur pada Pasar Papringan Dusun Ngadiprono, Desa Ngadimulyo, Kecamatan Kedu, Temanggung.

Lestari, Susi (2009). Pengembangan Desa Wisata dalam Pemberdayaan Masyarakat. Yogyakarta:UIN Sunan Kalijaga.

Moleong, Lexy J. (2007). Metodologi Penelitian Kualitatif. Bandung: PT Remaja Rosdakarya Offset.

Muljadi. (2016). Kepariwisataan dan Perjalanan. Jakarta: Rajawali Pers.

Nugroho, Iwan dan Purnawan D. Negara. (2015). Pengembangan Desa Melalui Ekowisata. Surakarta: PT. Era Adicitra Intermedia.

Pemerintah, P. (2009). Peraturan Menteri Dalam Negeri Nomor 33 Tahun 2009 Tentang Pedoman Pengembangan Ekowisata di Daerah. Jakarta: Menteri Dalam Negeri.

Pendit, Nyoman, S. (2002). Ilmu Pariwisata Sebuah Pengantar Perdana. Jakarta: PT. PradnyaParamita

Yopa, K. A. (2017). Model Pemberdayaan Ekonomi Masyarakat melalui Desa Wisata Budaya di Kebondalemkidul, Prambanan, Klaten, Jawa Tengah.Skripsi--Universitas Negeri Yokyakarta. Yokyakarta. 